\title{
E-Learning for Society: A Great Potential to Implement Education for All (EFA) Movement in Indonesia
}

\author{
https://doi.org/10.3991/ijim.v14i02.11363 \\ Nuur Wachid Abdul Majid ( $\left.{ }^{凶}\right)$, Syifaul Fuada \\ Universitas Pendidikan Indonesia, Bandung, Indonesia \\ nuurwachideupi.edu
}

\begin{abstract}
UNESCO has designed the education concept through the EFA movement; thus, the SDGs can be achieved optimally. This movement is expected to create quality education that can be reached by all people, mainly to whom live in villages far from big cities. The effort to equalize education must be supported by recent technology, especially since the penetration of technology into various fields had been introduced simultaneously. E-learning has many benefits, and it can support wide-scale learning. The e-learning concept in Indonesia has been adopted through a digital platform, namely Massive Open Online Courses (MOOCs). There are various publications related to e-learning application for formal education, while the discussion of e-learning for nonformal education is still limited and has not much explored. Following are the results of this literature study (1) e-learning is a digital-based learning tool that has been implemented in most of the universities and higher educations; (2) elearning application for society cannot be realized because there are many problems (such as low technical skill of the society, so they have difficulty in accessing technology and the facilities support have not been distributed well. Hence it can not be reached massively by the society), resulting the technology utilization for training or counseling have not been implemented optimally yet; and (3) MOOCs are part of e-learning that can be employed by everyone, not only for academics but also for the general public, providing various features like formal education.
\end{abstract}

Keywords-E-Learning, education for all, nonformal education, MOOCs

\section{Introduction}

Equitable education is the primary step that must be implemented by the government, one of which is to improve learning facilities as well as schooling opportunities for the society in remote areas. The equitable education program is in line with the quality of education improvement, which is part of the sustainable development goals (SDGs). UNESCO has designed the concept of learning that is Education for All (EFA) Movement so that SDGs can be fulfilled maximally.

At present, the condition of Indonesia's education is still relatively low even though the expansion access to schools for the society with competition in the global. Government policies to seek education for all Indonesian citizens should be continu- 
ously carried out, starting from the scholarships provision for basic level education to higher education (universities). As the third largest population in the world, Indonesia would be a developed country if it is supported by high-quality human resources [2].

The Governments have been developing city planning integrated with technology as one of the smart city programs. A smart city is a solution to facilitate several primary information related to the city condition in a real-time. It was an important issue for many sectors related to cooperation, such as political, international, \& regional relationships, and also the countries life of nation [3]. Online learning can be an alternative to building the society, in which it can be reached evenly and freely accessible for everyone.

Students gain experience in which they can apply it to similar cases in the future through technology-based learning [4]. E-learning offers many advantages, it has a positive relationship between staffs, educational e-services, and knowledge values in conjuction with students' satisfaction [5] and many other benefits compared to traditional teaching methods [6]. In addition, e-learning can improve the education qualities by accessing global scale academic learning resources and proposing special training for academics [7]. The results of the above study indicate the usefulness of elearning in increasing students' learning abilities, especially when e-learning is applied in the society. We expect, several positive impacts can be obtained.

Research topic related to e-learning is commonly covers the formal education, while the theme for non-formal education is still rarely. The research, as discussed above, has not tried to investigate the e-learning usefulness for the society. E-learning concept has been adopted through the Massive Open Online Courses (MOOCs) which has implemented in Indonesia. The MOOCs model will grow continuously in Indonesia, a country which has a large population. Therefore, users can increase their knowledge significantly, along with the addition of facilities to the society and improvement of education and training services [8]. Ismail et al. found that MOOCs can increase several learning outcomes of the students, comprising their interest, computer literacy, and their learning styles. Furthermore, MOOCs makes the learning process more interesting [9].

This paper aims to find out the potential aspect of learning that was applied to Indonesian. The Indonesia people who are familiar with technology will access elearning easily. Therefore, e-learning application can be developed well as expected. However, there is a need to assess the e-learning implementation for this potential aspect, covering communities based on culture, and geographical location in Indonesia.

We can use this paper results as a preliminary study to examine further about elearning applications, especially in Indonesia. Moreover, it can help to generalize differences based on the territory in Indonesia, by e-learning development. We expect that the Education for All (EFA) movement can work well because e-learning can be a medium for transferring knowledge to the broad society. 


\section{E-Learning Application in Indonesia: Overview}

In general, e-learning was applied to support the learning carried out by the teacher. Hence, learning in the class becomes interactive and easily understood by students. Also, by using e-learning, students can access material quickly and comprehensively and have an impact on learning outcomes optimally. In recent years, MOOC is considered as one of the excellent innovations in education field. [10]. "MOOCs" along with the keywords "Open Educational Resources (OER)" and "Web 2.0" often appear in the internet search nowadays, [11]. The existence of MOOCs is increasingly massive with the presence of 4 th industrial revolution euphoria.

The existence of e-learning and MOOCs in Indonesia supports and strengthens government programs in the education sector, specifically Technical \& Vocational Education and Training (TVET). TVET aims to prepare a workforce with excellent skilled, high-quality competencies, and global competitiveness capability. Through TVET, the graduate from vocational school will contribute to future technology (advanced technology mastership) and labor-based economy [12]. Technology development in the education field can certainly help students to achieve learning outcomes that have been designed by stakeholders.

\section{$3 \quad$ Results and Analysis}

\subsection{E-learning concept}

Education requires a long implementation process and also needs optimal learning media so that student learning outcomes can be achieved well. Learning media will continue to experience developed over time. In the 4th industrial revolution to date, almost all fields use technology, including the education sector. Technology is a significant supplement of the learning patterns development in the classroom. Further use of technology can be realized through curriculum improvement [13]. The learning process in formal education changes the students' learning behavior [14].

E-learning focuses on the interaction among teachers, learners, and online environment [15]. This concept can be adopted as a supporting media for 21 st-century learning. A teacher can upload learning material (videos, e-books, animations, and so on) onto e-learning, while students can access it freely. Also, e-learning is designed flexibly through the internet for supporting students to achieve learning outcome [16]. But, the disadvantage one of e-learning requires a stable and high-speed internet connection and needs a device (e.g., personal computer, smartphone, laptop) as an interface [17]. In the future, students will live as adults with many tasks and many aspects. They also will be driven by technology that highly diverse and dynamic [18]. Elearning is a blended learning that combines online learning methods with traditional education. Fundamentally, blended learning redesigns instructional models to accelerate future learning and career preparation [19].

Sharma has evaluated the impact of the use of technology, gender, and skills on student attitudes with e-learning [13]. They found that students' behavior using e- 
learning was different from conventional learning. In e-learning, students are trained to critically think when finding problems and trying to solve it so they will gain a problem-solving skill. Students are also required to be active in accessing web-based or smartphone-based e-learning on the internet. Various systems have been implemented that are dedicated to higher education to facilitate web-based learning, including MoodleTM [16].

The application of e-learning is an effort to improve the education quality in Indonesia that is still relatively low to this date. The output of education quality is also caused by the teacher's competence [20]. While the teacher's quality must also be supported by multimedia, so the role of e-learning is very high to help them in mastering it. In other hands, e-learning can motivate the students to stimulate their abilities flexibly without limiting critical thinking and also problem-solving skills.

The development of e-learning began as a learning management system (LMS)based emerging platform such as MoodleTM that is a course management system (CMS), an open source software package that can be access freely. The educators can create an online-based learning media effectively using CMS [21][22]. Many universities and higher schools are using MoodleTM as CMS to support e-learning. With regard the MoodleTM statistics, 107,304 currently active sites have registered from 226 countries. Besides, MoodleTM is very popular that has been used by worldwide users because of its easy configuration, friendly user, and it can be combined with various devices.

Furthermore, many universities and schools do not use CMS (like MoodleTM) in developing e-learning portals. E-learning development has an advantage that it can display something on the portal according to the user's needs and desires. While the use of CMS is usually already defaulted automatically, although it can still be developed again. The CMS is generally more vulnerable than a self-developed system. So, the security aspect is relatively low when we employed a CMS-based e-learning system. Universitas Pendidikan Indonesia is one of the universities that develops elearning portals without the CMS utilization as visualized in Figure 1.

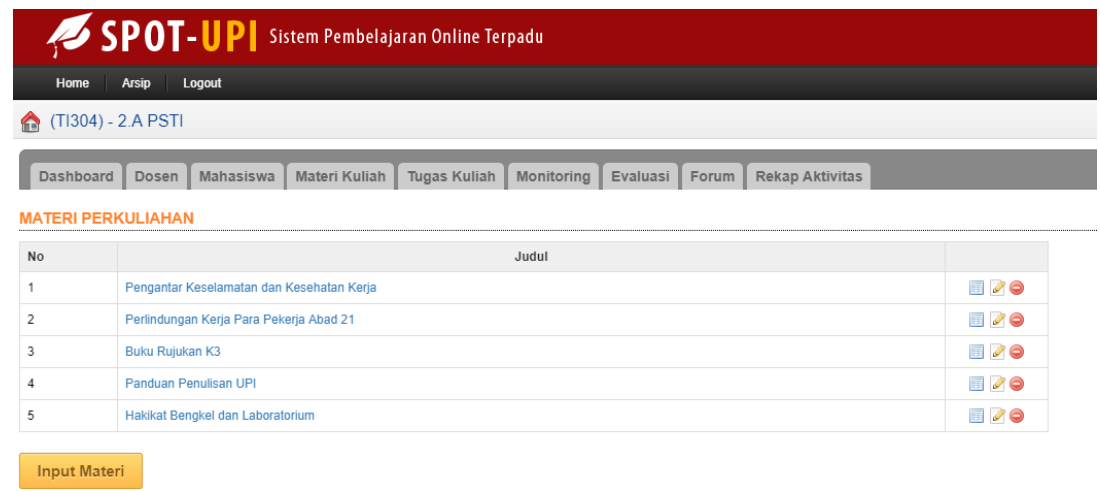

Fig. 1. E-learning in the Universitas Pendidikan Indonesia (captured on June 2019) 


\subsection{Learning platform for society}

The e-learning portal development for the society has been started since the appearance of MOOC in 2009. MOOC is a technology-based learning media that can be accessed by everyone (all people) so they still have an opportunity to gain an education in the future. Perhaps MOOCs can be considered as "innovation platform," this is a media to learn and experiment comprising a modern pedagogy which can be utilized by the institution. [23]. The concept of the MOOC will be increasingly recognized by the society. Accordingly, it is possible to be an educational landscape in the future.

The features provided by MOOCs are no different from e-learning at universities, it also serves the courses in which several learning materials are delivered for a specified period. The IndonesiaX as depicted in Figure 2 is one of the MOOCs that has developed with some content shared. There are presenters from great and famous people to deliver courses following their fields of expertise, while the users can choose the material provided only according to their interests and competencies to be mastered.

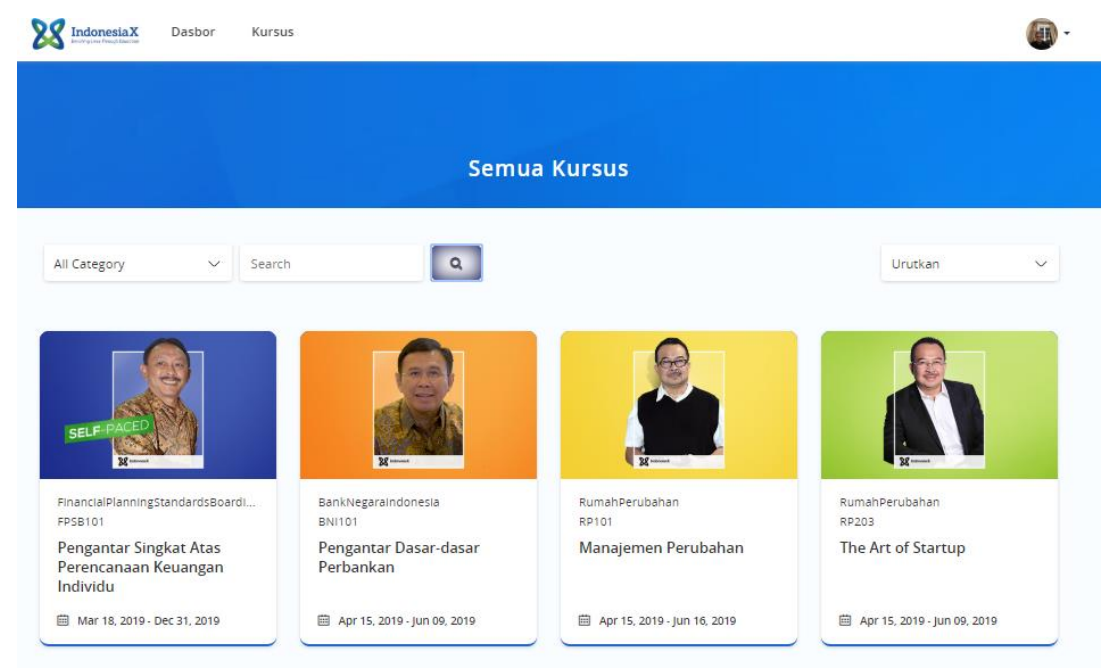

Fig. 2. IndonesiaX is one of the MOOCs in Indonesia (captured on June 2019)

As in IndonesiaX, each session contains learning contents as visualized in Figure 2, i.e., videos and text-based material (pdf or doc. format) uploaded on the system. The users can follow each course and learn the given material. At the end of the session, a specific exam is provided to the students as users. Thus, users will know their capabilities. When graduating, the users will get a certificate with an obtained score to notify that they have taken the courses.

MOOCs are still considered as "non-formal" education although it is effortless for users to follow the material provided. Accordingly, the learning achievements in the MOOCs do not automatically and immediately get an official degree and formal education accomplisment at the university. But some experts believe that the MOOC will 
become a future educational landscape in 4.0 era and it will compete with the "formal" education.

The Special Region of Yogyakarta (Daerah Istimewa Yogyakarta/DIY) government has issued a policy by creating an official portal as a learning media for the society. The "Jogja Learning" as shown in Figure 5 becomes an icon of the MOOC developed through Balai Teknologi Komunikasi Pendidikan (BTKP), DIY, Indonesia. BTKP provides several learning materials in Jogja Learning as part of a technologyassisted society education program. Moreover, Jogja Learning becomes a platform that should be used by Yogyakarta's people only including teachers, students, and parents. The "Jogja belajar" (JB) Class is a MOOC-based learning spot that has several features, including courses, quizzes, guidance, etc.

As mentioned before, the JB Class' users are divided into three parts, namely teachers, students, and parents. To use this platform, firstly the teachers must show their teacher ID (In Indonesia is called as NUPTK) during the registration process. While the DIY's students can use this platform with their student ID (In Indonesia is called as KIS). Even though currently JB Class is still specifically aimed at teachers and students, further development of JB Calss can be applied to a wider society like IndonesiaX.

\subsection{Implementation of e-learning in society}

Generally, people in Indonesia are still educated with conventional learning through village counseling agency. The concept of e-learning always presents challenges when it is developed in the society because of various problems. Although government efforts for equal education program have now reached rural areas (resulting in rural children can enter an education program in higher education from the undergraduate degree to the doctor), e-learning applied to booby boomers seems to have some problem because the average person who has to understand technology exists in the "Y" generation category to the Alpha generation.

This condition is complicated for stakeholders and the EFA movement activists to apply e-learning over the broad communities. The public needs to be introduced and trained with technology-based learning massively. Thus, the e-learning implementation will not occur several constraints. Even though, e-learning constraints have not been applied in schools or universities recently due to teachers/lecturers are booby boomers and " $\mathrm{X}$ " generation's category. The impact is tough to implement technology-enabled learning; the application can only be applied by millennial teachers in the "Y" generation category.

Besides, the government must also prepare a qualified infrastructure. Accordingly, the application of technology-based learning can operate well in the villages. The government can give extensive training to the society immediately in which the training must involve various parties, including academics affiliated in higher education via society service programs. So, the synergy between academics, society, and government for educational equity purpose can be realized. In summary, the EFA Movement can work well as predicted if these elements can synergize optimally. 


\section{Conclusion}

From the literature review results, we can conclude that e-learning has been implemented in most of the universities and higher educations. But it has not been applied to society massively because there are many problems that the mastery of technology for most booby boomers is still low. MOOCs are part of e-learning which can be accessed by all people easily. By using MOOCs-based e-learning, they will obtain many benefits optimally. This is called as e-learning application for non-formal education. However, training or counseling on the use of technology for learning has not run optimally yet because the educational facilities have not been reached by the wide-scale communities.

\section{$5 \quad$ References}

[1] Y. Fauzie, "Bank Dunia: Kualitas Pendidikan Indonesia Masih Rendah," CNN Indonesia, 2018. [Online]. Available: https://www.cnnindonesia.com/gaya-hidup/20180607113429284-304214/bank-dunia-kualitas-pendidikan-indonesia-masih-rendah. [Accessed: 25-May2019]. https://doi.org/10.21002/jaki.2012.02

[2] S. Manik, "Pemerataan Pendidikan Melalui Peningkatan Mutu Pendidik," Beritasatu, 2017. [Online]. Available: https://www.beritasatu.com/opini/5268-pemerataan-pendidikanmelalui-peningkatan-mutu-pendidik.html. [Accessed: 25-May-2019]. https://doi.org/10.23 $\underline{887 / j s t-u n d i k s h a . v 1 i 1.1417}$

[3] S. Saravani, H. B. Ghafoori, and F. Shokraneh, "Feasibility of medical education through email: Case study of darsnameh e-learning system," in 5th Electronic Learning Congress in Medical Education, 2012.

[4] Y. Hendawati, S. Pratomo, Suhaedah, N. A. Lestari, T. Ridwan, and N. W. A. Majid, "The Impact of Approach Contextual Teaching and Learning Science to Improve Understand the Ability of Elementary School Student Concept,” J. Phys. Conf. Ser., 2019. https://doi.org/ $\underline{10.1088 / 1742-6596 / 1318 / 1 / 012130}$

[5] R. A. El Aziz and H. A. El Halim, "Assessing Criteria That Matter To Students' Satisfaction in Private Higher Education," Int. J. Adv. Inf. Technol., vol. 8, no. 4/5, pp. 1-14, 2018. https://doi.org/10.5121/ijait.2018.8501

[6] M. B. Nejad and E. B. Nejad, "Impact of E-Learning on Learning and Realizing Information Society,” Res. J. Appl. Sci. Eng. Technol., vol. 4, no. 3, pp. 5016-5020, 2012.

[7] S. El Gamal and R. A. EL Aziz, "The Perception of Students Regarding E-Learning Implementation in Egyptian Universities: The Case of Arab Academy for Science and Technology," in The Third International Conference on Mobile, Hybrid, and On-line Learning, 2011.

[8] W. Purnomo, "Penerapan Massive Open Online Course (MOOC) berbasis Moodle sebagai Learning Management System (LMS)," in Simposium Nasional Pengembang Teknologi Pembelajaran, 2016.

[9] M. E. Ismail, P. Utami, I. M. Ismail, N. Hamzah, and H. Harun, "Development of Massive Open Online Course (MOOC) Based on ADDIE Model for Catering Courses," J. Pendidik. Vokasi, vol. 8, no. 2, pp. 184-192, 2018. https://doi.org/10.21831/jpv.v8i2.19828

[10] J. Shen, M. Ye, Y. Wang, and Y. Zhao, "Massive Open Online Course (MOOC) in China: Status quo, opportunities, and challenges," in IEEE Global Engineering Education Conference (EDUCON), 2016, pp. 1106-1108. https://doi.org/10.1109/educon.2016.7474692 
[11] Berlianto and H. . Santosa, "Indonesian Perspective on Massive Open Online Courses: Opportunities and Challenges," J. Educ. Online, vol. 15, no. 1, 2018.

[12] O. Osman, "Perutusan NC 2016-APEX 2020: Merialisasikan Universiti Global," Universiti Sains Malaysia, 2016. [Online]. Available: http://www.eng.usm.my/index.php/ms/morearticles/211-perutusan-nc-2016-apex-2020-merealisasikan-universitiglobal. [Accessed: 20May-2019]. https://doi.org/10.21315/jps2016.27.2.9

[13] A. M. Zabadi and A. H. Al-Alawi, "University Students' Attitudes towards E-Learning: University of Business \& Technology (UBT)-Saudi Arabia-Jeddah: A Case Study,” Int. J. Bus. Manag., vol. 11, no. 6, pp. 286-295, 2016. https://doi.org/10.5539/ijbm.v11n6p286

[14] Y. D. L. Widyasari, L. E. Nugroho, and A. E. Permanasari, "Persuasive technology for enhanced learning behavior in higher education," Int. J. Educ. Technol. High. Educ., vol. 16, no. 15, pp. 1-16, 2019. https://doi.org/10.1186/s41239-019-0142-5

[15] S. Codone, An E-learning Primer. Florida: Pensacola, 2001.

[16] T. Kattoua, M. Al-Lozi, and A. Alrowwad, "A Review of Literature on E-Learning Systems in Higher Education,” Int. J. Bus. Manag. Econ. Res., vol. 7, no. 5, pp. 754-762, 2016.

[17] A. Alenezi and K. Hahi, "Interactive E-Learning through Second Life with Blackboard Technology,” Procedia Soc. Behav. Sci., vol. 176, pp. 891-897, 2015. https://doi.org/10.10 16/j.sbspro.2015.01.555

[18] H. Suwono, "School Literary Movement in Indonesia: Challenges for Scientific Literacy," in Education in the 21th Century: Responding to Current Issues, International Conference on Education, 2016, pp. 309-317.

[19] K. C. Dewi, P. I. Ciptayani, H. D. Surjono, and Priyanto, "Modeling Vocational Blended Learning Based on Digital Learning Now Framework," TOJET Turkish Online J. Educ. Technol., vol. 17, no. 2, pp. 89-96, 2018. https://doi.org/10.2991/icst-18.2018.130

[20] Abrori, "Improving Reading Literacy Strategy through Seven Programs of Reading Interest containing Da'wah Message," Attarbiyah J. Islam. Cult. Educ., vol. 3, no. 2, pp. 205225, 2018

[21] Moodle, “About Moodle," Moodle.org, 2018. [Online]. Available: https://docs.moodle.org/37/en/About Moodle. [Accessed: 04-Jun-2019]. https://doi.org/10. 4135/9781483318332.n244

[22] E. Rochmah and N. W. A. Majid, "Manajemen Pembelajaran Interaktif Berbasis Moodle," 2017.

[23] M. Brown, E. Costello, E. Donlon, and M. N. Giolla-Mhichil, "A strategic response to MOOCs: How one European university is approaching the challenge," Int. Rev. Res. Open Distrib. Learn. vol. 16, no. 6, pp. 98-115, 2015. https://doi.org/10.19173/irrodl.v16i6.215 1

\section{Authors}

Nuur Wachid Abdul Majid received a B.Ed. in Informatics Engineering of Education and a M.Ed. in Technology and Vocational Education, Universitas Negeri Yogyakarta, Indonesia. Now, he is a lecturer of Program Studi Pendidikan Sistem dan Teknologi Informasi, Universitas Pendidikan Indonesia. His research interest including Technology and Vocational Education, Instucional Media for Learning, Social experiment, and Informatics. 
Syifaul Fuada, received a B.A. in Electrical Engineering Education from Universitas Negeri Malang (UM), Indonesia, and an M.Sc. in Electrical Engineering option Microelectronics from the School of Electrical Engineering and Informatics, Institut Teknologi Bandung (ITB), Indonesia. He was with the University Center of Excellence at Microelectronics ITB from 2016-2018 as a main researcher. Now, he is with the Program Studi Sistem Telekomunikasi Universitas Pendidikan Indonesia (UPI) as a Lecturer. His research interests include analog circuit design and instrumentation, circuit simulation, engineering education, IoT, multimedia learning development and Visible Light Communication. syifaulfuada@upi.edu

Article submitted 2019-07-23. Resubmitted 2019-11-07. Final acceptance 2019-11-07. Final version published as submitted by the authors. 